\title{
Effect of Mentor Teaching on Learning Microbiology to Second Year M.B.B.S Students
}

\author{
R. Shyamala and P. Palavardhan* \\ Department of Microbiology, Department of Community Medicine, Malla Reddy Medical \\ College for Women, Hyderabad, Telanagana, India \\ *Corresponding author
}

Ke y w o r d s
Mentor teaching,
Microbiology,
M.B.B.S Students
Article Info
Accepted:
26 April 2020
Available Online:
10 May 2020

\section{A B S T R A C T}

\section{Introduction}

The role of a mentor has long been understood as invaluable in helping an individual learn something new. The origin of the word mentor dates back to Greek mythology in Homer's The Odyssey (1961), in which Odysseus' most loyal friend Mentor was charged with educating Odysseus' son Telemachus in every aspect of life, including helping him to recognize and to learn from " his own errors in judgement" (1). This 
relationship, in which a wiser and more learned individual plays a role in supporting the development of a more inexperienced novice, is demonstrated throughout history in the relationships of Socrates, who mentored Plato, and Plato, who mentored Aristotle.

The value and importance of a mentor in facilitating one's learning is further supported by the work of educational psychologists, including Vygotsky's conception of a "more knowledgable other" - one echo helps another move from one point to a point beyond where they could get on their own- and is demonstrated repeatedly in the field of education through research and practice in many books, journal articles. (1).

Mentor teaching is a valuable strategy to provide students with the emotional and instrumental support students need to achieve the goal of a college degree. By providing information, guidance, and encouragement, mentors can play an important role in nurturing students' college aspirations . Mentoring for students in college helps students to feel more connected and engaged on campus, which can ultimately improve student outcomes (2). Because of the prevalence of mentoring in various settings and the wide range of issues mentors address, scholars have struggled to develop a common definition of the term. In fact, there are over 50 different definitions of mentoring in the social science literature some describe mentoring as a concept or process, while other use the term to describe a specific set of activities. Yet, across research studies, common characteristics of mentoring emerge. They include: a) learning partnership between a more experienced and a less experienced individual; a process involving emotional (friendship, acceptance, support) and instrumental (information, coaching, advocacy, sponsorship) functions ; and a relationship that becomes more impactful over time. Others discuss nurturing the mentee's social and psychological development, serving as a role model and providing support for goal setting and future planning.

In a discussion on mentoring, Gasner (2006) described the changing nature of mentoring programs and noted that, historically, mentoring was a fairly straightforward endeavour. Mentors were selected based on their willingness to work with a new teacher without receiving any incentive and with no release from other obligations.

Additionally, mentoring included little or no training, as the skills of good teachers were the same as those of a good mentor. Therefore, the goals of mentoring were limited to emotional support, a level of technical assistance, and an orientation to the local culture"

\section{Materials and Methods}

In this study 30 students of second year M.B;B.S students of Malla Reddy Medical College for Women were selected in the subject of Microbiology for Mentor teaching. Institutional ethical committee clearance was obtained

Study period: 5 months (October 2017February 2018) Settings: Department of Microbiology, Malla Reddy Medical College for Women, Hyderabad Study population: Second MBBS students - 30 students Subject - Microbiology Student consent was taken. The Mentor Teaching is done by a five phased approach

Phase 1 - Forming Stage

Phase 2 - Storming Stage

Phase 3 - Norming Stage

Phase 4 - Implementing stage

Phase 5- Evaluating Stage 
30 students were included in the mentor teaching. Three classes per week were taken. the topic was explained to them in detail. Before teaching the topic a pretest questionnaire will be given, because the topic is already covered in the theory class. At the end of the week a post test questionnaire is given to them.

Both pretest and post test are compared of individual students to see the improvement in the performance. After mentor teaching any doubts among the individual students will be cleared to their satisfaction.

\section{Results and Discussion}

In my project of this mentor teaching of 5 months duration I have conducted 3 tests to my mentees. In the first test their average scores were low i.e., $30 \%$. In the second test the average scores improved to $60 \%$. In the final third test the average scores improved by $80 \%$. Thus showing significant improvement in their performance.

Table.1 Students' perception regarding mentor teaching as a teaching method in microbiology

\begin{tabular}{|c|l|l|l|}
\hline S. No. & Items & Yes & No \\
\hline $\mathbf{1 .}$ & $\begin{array}{l}\text { Mentor teaching is less } \\
\text { stressful as compared to } \\
\text { traditional teaching. }\end{array}$ & $\begin{array}{l}90 \% \text { students } \\
\text { said yes. }\end{array}$ & $\begin{array}{l}10 \% \text { students } \\
\text { said No }\end{array}$ \\
\hline $\mathbf{2 .}$ & $\begin{array}{l}\text { Mentor teaching } \\
\text { eliminates bias }\end{array}$ & $\begin{array}{l}100 \% \text { students } \\
\text { agreed }\end{array}$ & Nil \\
\hline $\mathbf{3 .}$ & $\begin{array}{l}\text { Mentor teaching } \\
\text { highlighted the areas of } \\
\text { weakness }\end{array}$ & $\begin{array}{l}80 \% \text { students } \\
\text { agreed }\end{array}$ & $\begin{array}{l}20 \% \text { students } \\
\text { disagreed }\end{array}$ \\
\hline $\mathbf{4 .}$ & $\begin{array}{l}\text { Mentor teaching helps to } \\
\text { score better }\end{array}$ & $\begin{array}{l}100 \% \text { students } \\
\text { agreed }\end{array}$ & Nil \\
\hline $\mathbf{5 .}$ & $\begin{array}{l}\text { Mentor teaching helps } \\
\text { passing the exams easy }\end{array}$ & $\begin{array}{l}100 \% \text { students } \\
\text { agreed }\end{array}$ & Nil \\
\hline $\mathbf{6 .}$ & $\begin{array}{l}\text { Mentor teaching covered } \\
\text { wide knowledge area }\end{array}$ & $\begin{array}{l}90 \% \text { students } \\
\text { agreed }\end{array}$ & $\begin{array}{l}10 \% \text { students } \\
\text { disagreed }\end{array}$ \\
\hline $\mathbf{7 .}$ & $\begin{array}{l}\text { Mentor teaching helps to } \\
\text { learn better }\end{array}$ & $\begin{array}{l}90 \% \text { students } \\
\text { agreed }\end{array}$ & $\begin{array}{l}10 \% \text { students } \\
\text { disagreed }\end{array}$ \\
\hline $\mathbf{8 .}$ & $\begin{array}{l}\text { Mentor teaching helps } \\
\text { the students to feel more } \\
\text { connected and engaged } \\
\text { on the campus }\end{array}$ & $\begin{array}{l}70 \% \text { students } \\
\text { agreed }\end{array}$ & $\begin{array}{l}30 \% \text { students } \\
\text { disagreed }\end{array}$ \\
\hline $\mathbf{9 .}$ & $\begin{array}{l}\text { Mentor teaching should } \\
\text { be continued in } \\
\text { Microbiology as a } \\
\text { teaching method }\end{array}$ & $\begin{array}{l}100 \% \text { students } \\
\text { agreed. }\end{array}$ & Nil \\
\hline
\end{tabular}


Table.2 Faculty perception regarding mentor teaching

\begin{tabular}{|c|c|c|c|}
\hline S No & Item & Yes & No \\
\hline 1. & $\begin{array}{l}\text { Mentor teaching is } \\
\text { helpful for students }\end{array}$ & $\begin{array}{l}\text { All the faculty } \\
\text { agreed }\end{array}$ & Nil \\
\hline 2. & $\begin{array}{l}\text { Students } \\
\text { performance was } \\
\text { better after mentor } \\
\text { teaching }\end{array}$ & $\begin{array}{l}\text { All the faculty } \\
\text { agreed }\end{array}$ & Nil \\
\hline 3. & $\begin{array}{l}\text { Mentor teaching has } \\
\text { helped in improving } \\
\text { teaching skills. }\end{array}$ & $60 \%$ Faculty agreed & $40 \%$ Disagree \\
\hline 4. & $\begin{array}{l}\text { Mentor teaching } \\
\text { helped in better } \\
\text { performance in } \\
\text { practicals among the } \\
\text { students. }\end{array}$ & $70 \%$ faculty agreed & $30 \%$ Disagree \\
\hline 5. & $\begin{array}{l}\text { Mentor teaching } \\
\text { helped in better } \\
\text { performance of } \\
\text { students in theory }\end{array}$ & $90 \%$ faculty agreed & $10 \%$ faculty disagree \\
\hline 6. & $\begin{array}{l}\text { Mentor teaching } \\
\text { eliminates examiner } \\
\text { bias }\end{array}$ & $100 \%$ faculty agreed & Nil \\
\hline 7. & $\begin{array}{l}\text { Mentor teaching } \\
\text { should be continued } \\
\text { in Microbiology as a } \\
\text { teaching method. }\end{array}$ & $70 \%$ faculty agreed & $30 \%$ faculty agreed \\
\hline
\end{tabular}

Faculty Perception regarding Mentor Teaching

Graph.1

\section{Mentor teaching is less stressful as compared to traditional teaching.}

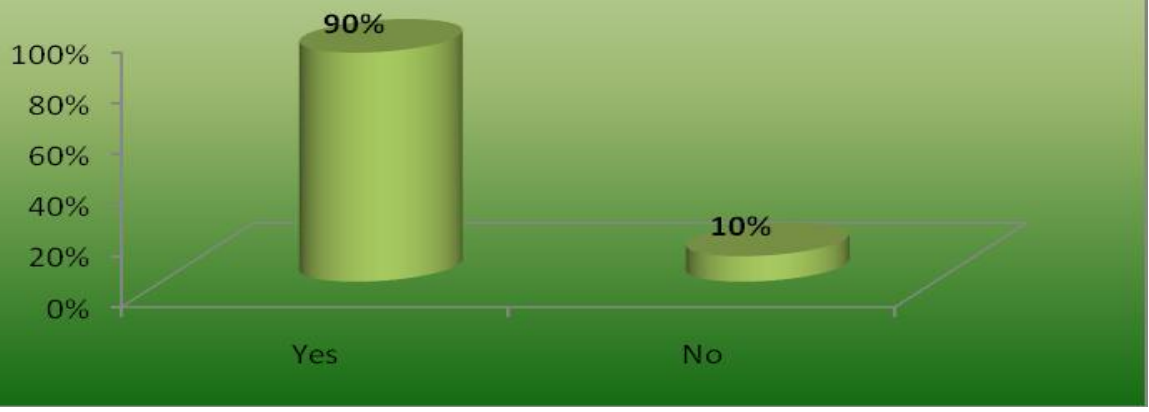


Graph.2

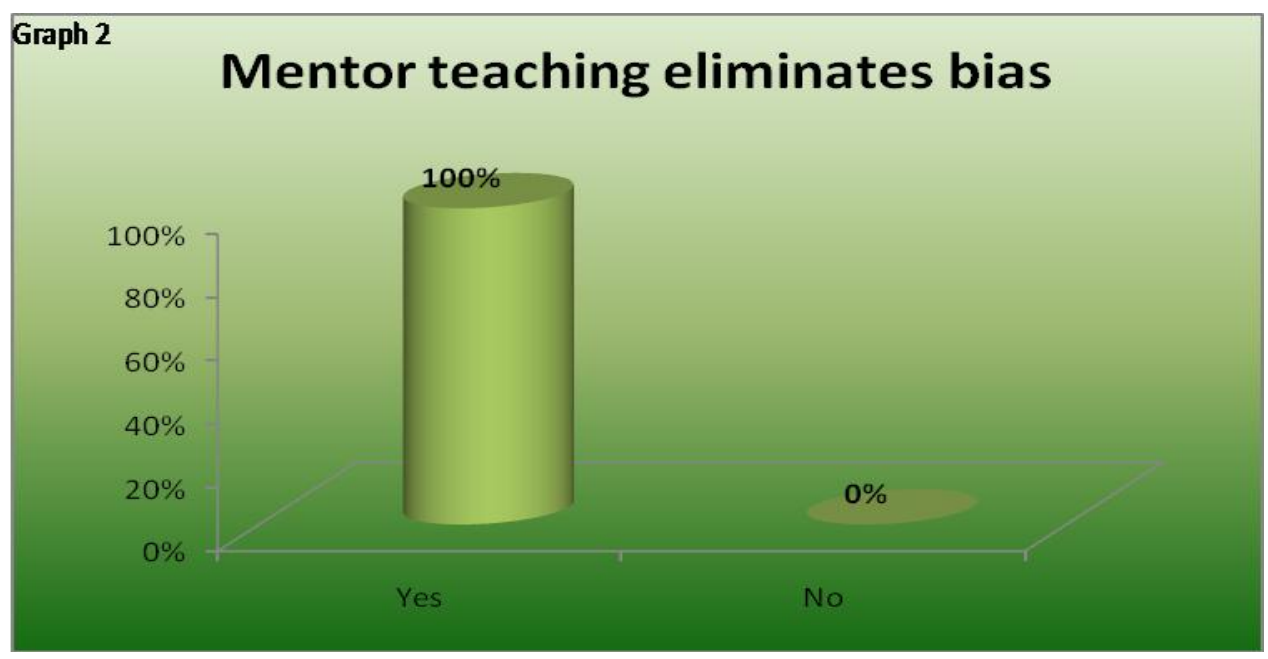

Graph.3

Mentor teaching highlighted the areas of weakness

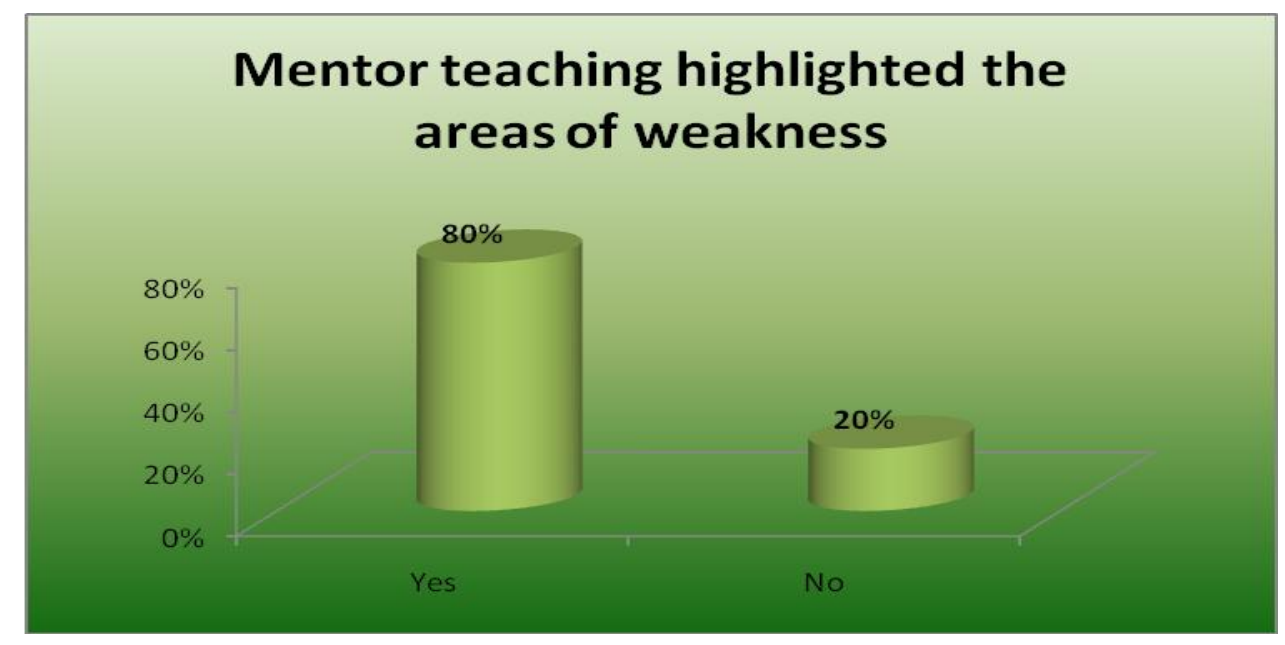

Graph.4

Mentor teaching helps to score better

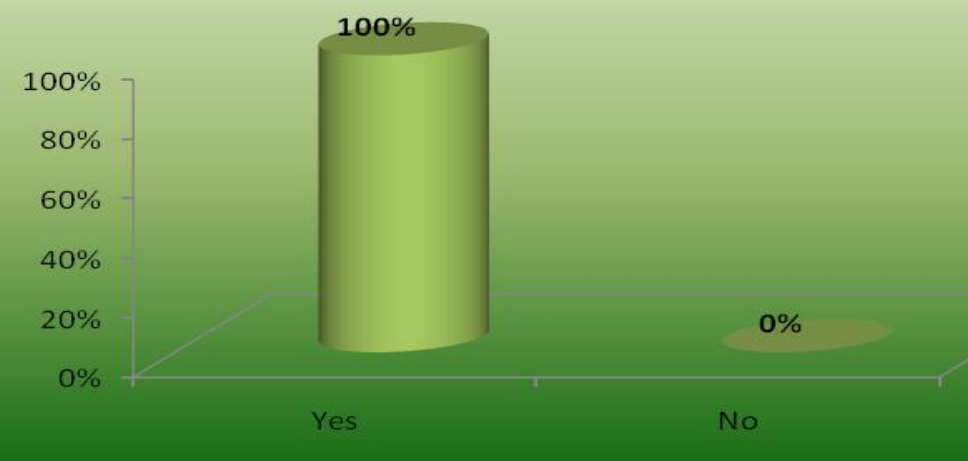




\section{Graph.5}

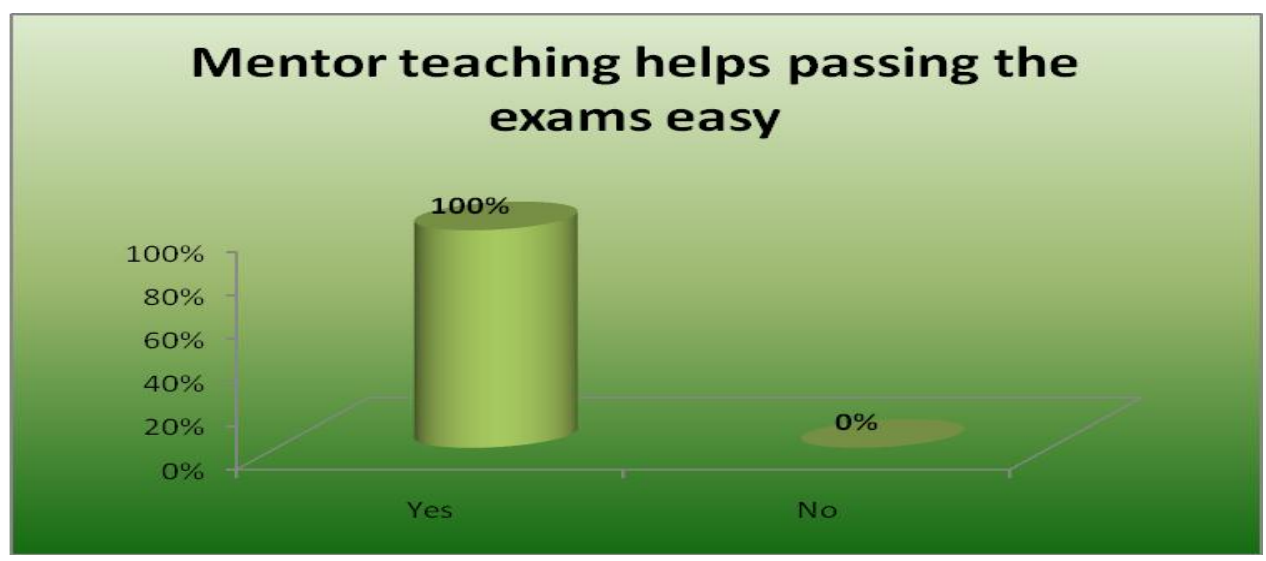

Graph.6

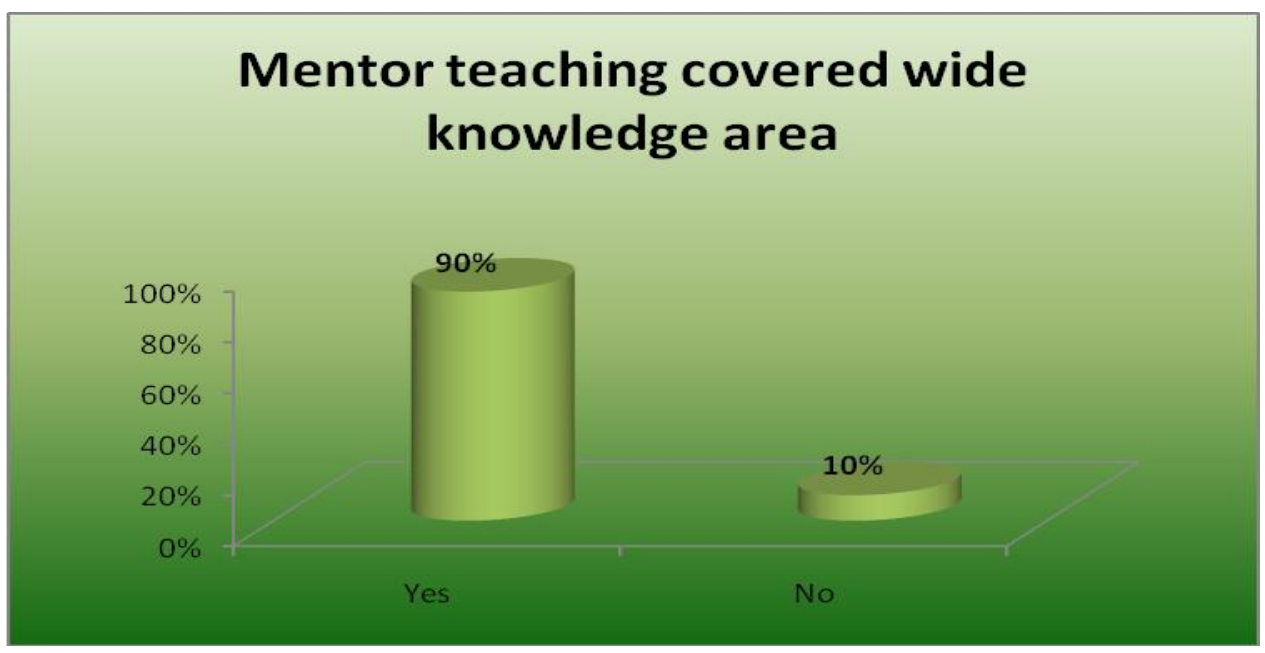

Graph.7

\section{Mentor teaching helps to learn better}

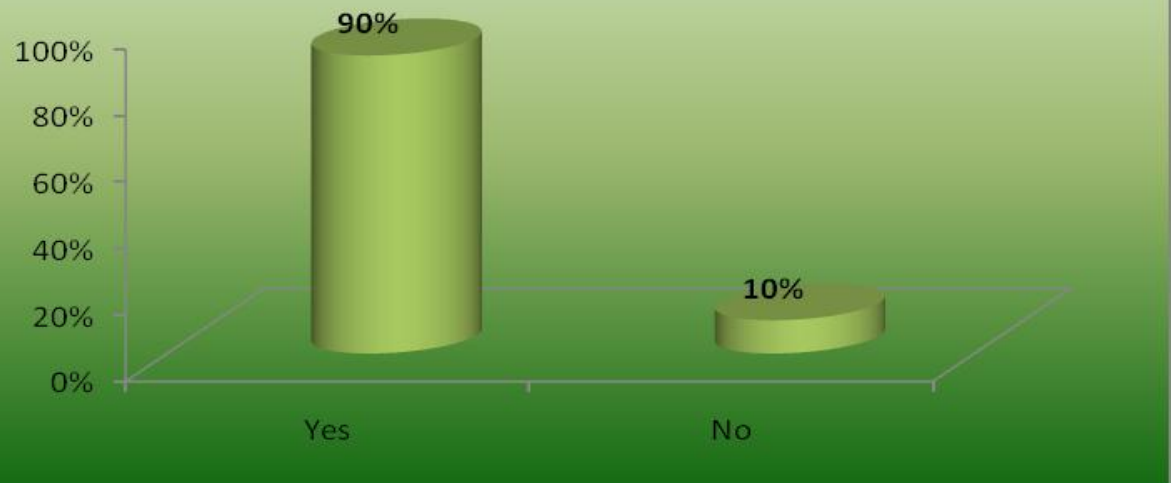




\section{Graph.8}

\section{Mentor teaching helps the students} to feel more connected and engaged on the campus

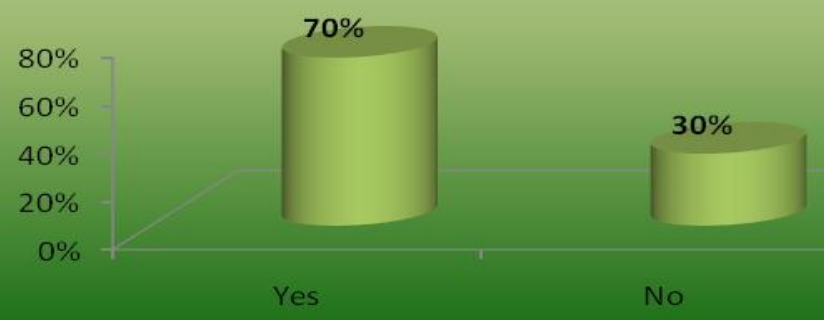

Graph.9

Mentor teaching should be continued in Microbiology as a teaching method

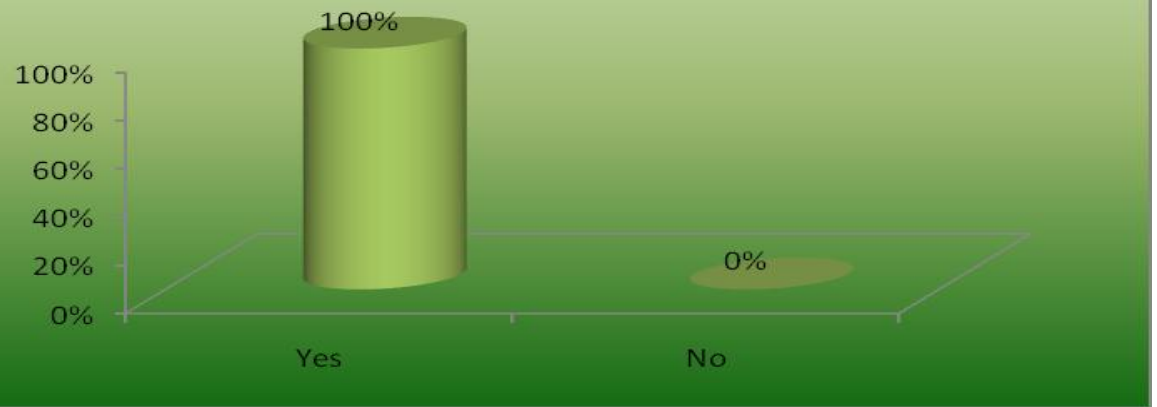

Graph.10

Mentor teaching is helpful for students

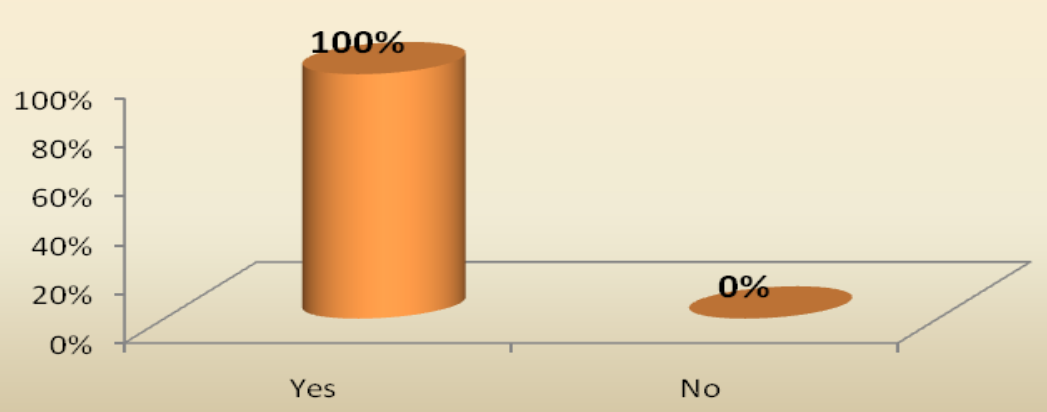


Graph.11

\section{Students performance was better} after mentor teaching

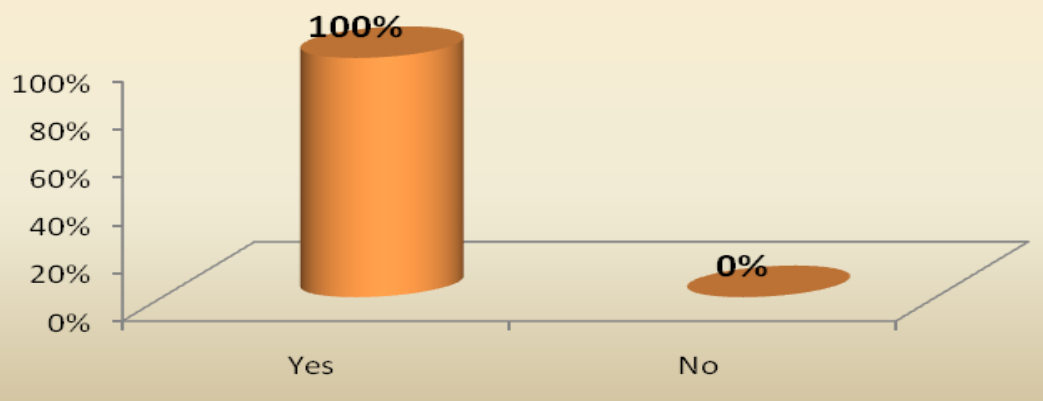

Graph.12

Mentor teaching has helped in improving teaching skills.

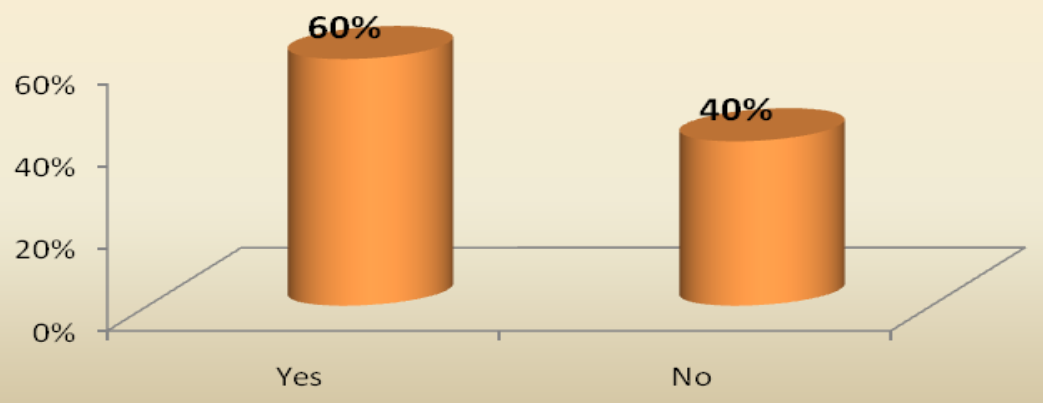

Graph.13

\section{Mentor teaching helped in better performance in practicals among the students.}

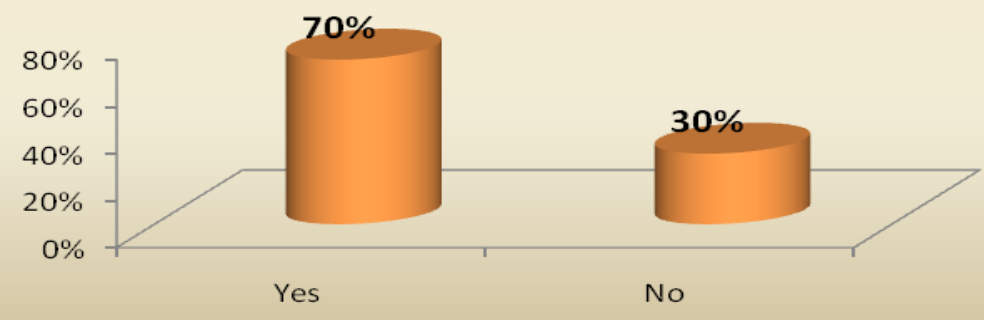


Graph.14

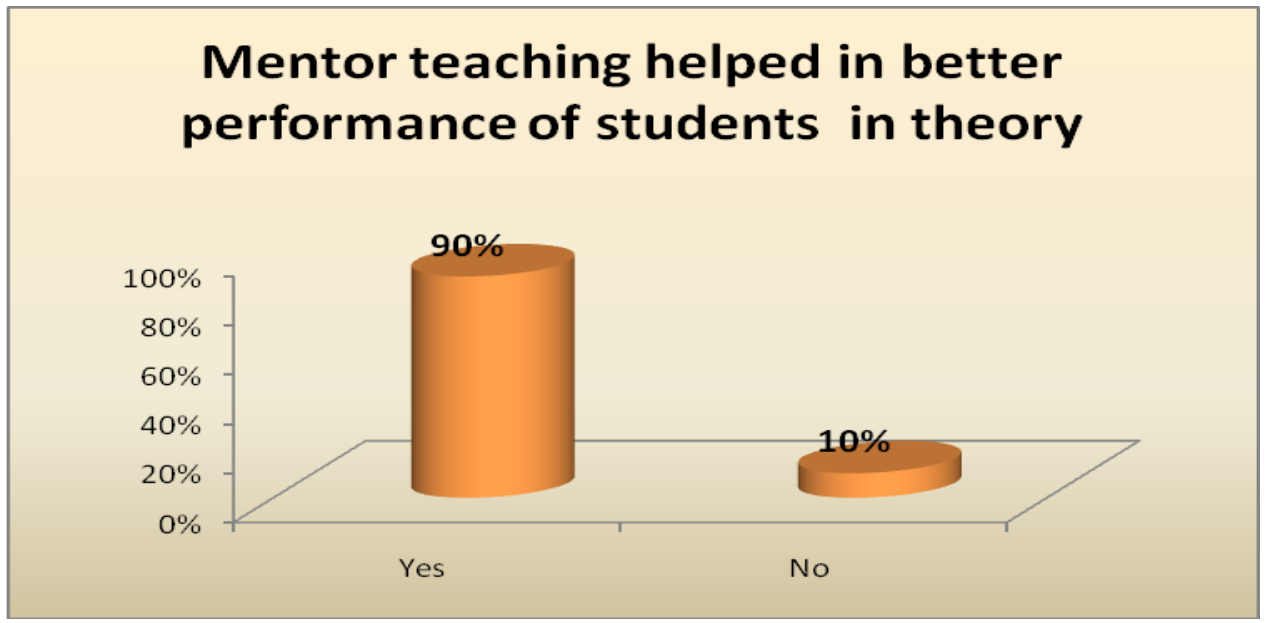

Graph.15

\section{Mentor teaching eliminates examiner bias}

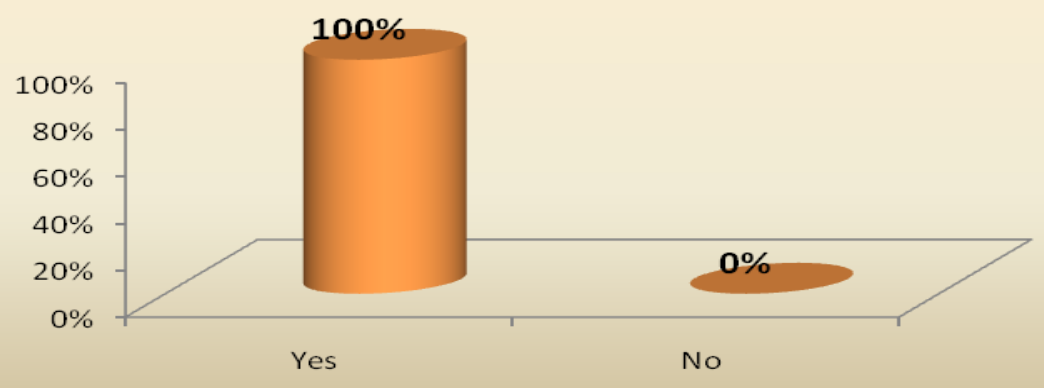

Graph.16

Mentor teaching should be continued in Microbiology as a teaching method.

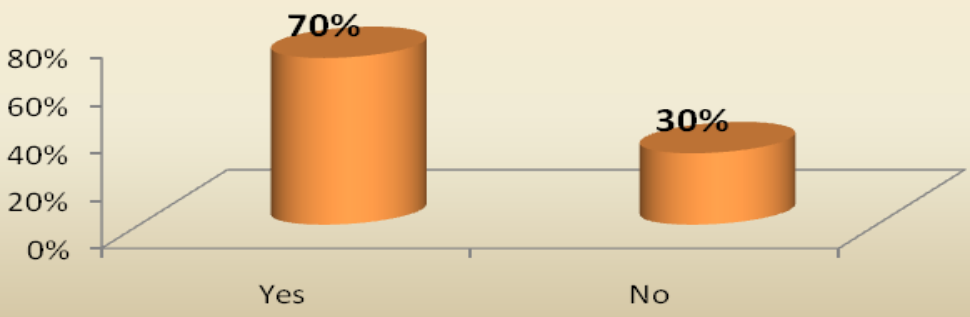


In this study the academic performance increased after mentor teaching.

Mentor teaching remains a viable policy option in education. However, for purposeful mentor teaching to occur, a prerequisite is the acceptance of its complexity in carrying out the mentoring function. This implies careful planning.

Teachers are valuable resources in education, and high quality performance in teaching is an essential ingredient of educational improvement or reform. To assist beginning teachers, it is necessary to support their performance in the classroom from the very beginning of their teaching careers. Quality teaching is essential if the mission of education is to be fulfilled. Mentoring can play a critical role in continually improving the professional knowledge and skills that teachers need to instruct and prepare students for the next century.

In conclusion, the students developed confidence, communication skills and they became more focused on their career(3),(4). The academic performance of the mentees is increased after undergoing mentor teaching (5),(6). The students had more confidence in writing the tests and in viva and clinical. The students felt that they should have mentor teaching as a part of the teaching schedule.
Mentor teaching helped the students in improving their confidence and communication skills. Mentor teaching is an additional tool for the students to revise the topics in a systematic way.

\section{References}

1.Odell, S. J. (1990). Mentor teacher programs. Washington, DC: National Education Association

2.Levin A. and Nidiffer, J. 1996. Beating the Odds : How the poor Get to College. San Francisco, CA: Jossey-Bass

3.Pascarella, E.T. 1980 " Student- faculty Informal Contact and College Outcomes". Review of Educational Research, 50, 545-595

4.Crisp, G and Cruz, I. 2009. " Mentoring College Students: A Critical Review of the Literature between 1990 and 2007." Research in Higher Education, 50: 525545

5.Roberts, A2000. “ Mentoring Revisited : A Phenomenological Reading of the Literature." Mentoring and Tutoring, $8(2), 145-170$

6.Bowman, R. L and Bowman, V.E. 1990. “ Mentoring in a Graduate Counselling Program: Students helping Students." Counsellor Education and Supervision, $30(1), 58-65$

\section{How to cite this article:}

Shyamala, R. and Palavardhan, P. 2020. Effect of Mentor Teaching on Learning Microbiology to Second Year M.B.B.S Students. Int.J.Curr.Microbiol.App.Sci. 9(05): 3258-3267. doi: https://doi.org/10.20546/ijcmas.2020.905.386 